Research Article

\title{
Biology of an Exotic Butterfly Acraea terpsicore (Linnaeus, 1758) (Nymphalidae: Heliconiinae), in a Newly Invaded Region, Sarawak, Borneo
}

\author{
Sabina Noor ${ }^{1 *}$, Fatimah Abang ${ }^{1}$ and Hamady Dieng ${ }^{2}$
}

${ }^{1}$ Faculty of Resource Science and Technology (FRST), Universiti Malaysia Sarawak (UNIMAS), Kota Samarahan, 94300, Malaysia, (Affiliation: Sardar Bahadur Khan Women's University, Quetta, 87300, Pakistan); Institute of Biodiversity and Environmental Conservation (IBEC), Universiti Malaysia Sarawak, Kota Samarahan, 94300, Malaysia.

\begin{abstract}
This study was intended to compare the immature stages of Acraea terpsicore (Linnaeus 1758) (tawny coster) relative to habitat types, phenotype, and gender in Sarawak, Borneo. The nymphalid butterfly tawny coster is widely distributed throughout the Indian and Sri Lankan region and has expanded its distribution range southward through Southeast Asia and Australia. Currently establishing its population in Kalimantan, it was firstly detected in Sarawak in 2013. Comparative observations on the life-cycle were conducted in relation to the urbanization levels. Passiflora foetida was recorded as the primary host plant of this species. Fecundity in a single cohort varied from 30 to 85 eggs, whereas eggs were oriented on the underside marginal areas of host plant leaves. The developmental time of $A$. terpsicore to complete its life cycle took an average of $30 \pm 3.01$ days with a total of five larval instars. The ontogenesis of larvae was accomplished without any disruption of diapause. The female adults were ochreous orange in color with a wingspan of about $50-60 \mathrm{~mm}$. The males were brighter orange in color and had a wingspan of about 40-50 mm. The population index was found to be common throughout the year but declined during months with higher precipitation. Being an exotic species, $A$. terpsicore is likely to keep track by feeding on its primary and famous $P$. foetida voraciously, in this newly invaded region. For future perspectives, a frequent investigation is suggested to countercheck the host plant dis-palatability and its role of becoming an invasive pest.

Received | September 17, 2019; Accepted | January 04, 2021; Published | March 02, 2021

*Correspondence | Sabina Noor, Faculty of Resource Science and Technology (FRST), Universiti Malaysia Sarawak(UNIMAS), Kota Samarahan, 94300, Malaysia, (Affiliation: Sardar Bahadur Khan Women’s University, Quetta, 87300, Pakistan); Email: sabina.noor15@yahoo.com

Citation | Noor, S., F. Abang and H. Dieng. 2021. Biology of an exotic butterfly Acraea terpsicore (Linnaeus, 1758) (Nymphalidae: Heliconiinae), in a newly invaded region, Sarawak, Borneo. Sarhad Journal of Agriculture, 37(1): 235-246.

DOI | http://dx.doi.org/10.17582/journal.sja/2021/37.1.235.246

Keywords $\mid$ Acraea, Exotic, Invasion, Sarawak, Borneo, Population
\end{abstract}

\section{Introduction}

The cosmopolitan Nymphalidae represents one 1 of the largest butterfly families, with about 7,200 species (Freitas and Brown, 2004). Among Nymphalidae, the subfamily Heliconiinae was reported exclusive to the Neotropics (Fox et al., 1965). In this subfamily, the tribe Acraeini have been reported in all tropical and subtropical regions of the world, especially in the Ethiopian region (Van Son, 1963). The genus Acraea (Fabricius, 1807) is widely distributed across the Paleotropics, with Africa recording greater prevalence compared to Asia (Larsen, 2005). Eltringham (1912), divided the genus into nineteen groups while, Van Son (1963), divided the Southern African species into twentythree groups based on their genitalia (Henning, 1992). The genus Acraea is almost confined to the 
Ethiopian region, with the presence of about 250 species and only four to five species are recorded from the Oriental and Indo-Australian regions (Van Son, 1963). Acraea terpsicore (Linnaeus, 1758) and Acraea issoria (Hübner, 1819) is the only species found in India (Kunte and Gadgil, 2001; Larsen, 2005; Hoskins, 2014). A. issoria is quite well established in the Indo-China region up to Taiwan (Emmel and Heppner, 1990). Though from Sulawesi Island the records of Acraea moluccana dohertyi (Holland, 1891) and Acraea moluccana parce (Staudinger, 1896) were reported but no clear observation of $A$. terpsicore has been documented (Vane-Wright and Jong, 2003). In Australia, only Acraea andromacha (Fabricius, 1775) was described (Braby et al., 2014).

A. terpsicore avoids dense vegetation and shades and is more commonly encountered along the vicinity of the larval host-plant where the larvae infest species of Passiflora, usually in open grasslands, wooden wreckage along roadsides, and dumped areas. It is a small leathery winged butterfly found in grasslands as well as scrub habitats (Kunte and Gadgil, 2001; Larsen, 2005). It is a colony-forming species, noticed in marginal habitats of Sri Lanka with more than half a dozen flying together and often on hot sunny days, in the form of swarms flying in savannah/ woodland mosaics (Hoskins, 2014). The larval host plants of $A$. terpsicore are characterized by numerous families, with most dominant evidence from the family Passifloraceae (Passiflora, Adenia) (Matsumoto et al., 2012; Das et al., 2010; Kaur et al., 2009) and Cucurbitaceae (Wikarmayanke and Wikramayanke, 2006). Passiflora genus consists of about 500 species across the globe with great genetic diversity. Passiflora foetida (Linnaeus, 1753) (Stinking/ Wild passionfruit) is widespread throughout the tropics and predominantly in Malaysia and Brunei (Waterhouse, 1994).

Being holometabolous insects, Lepidopterans do not acquire any further growth once they become adults (Garcia-Barros, 2000).During the transformation and growth period, the larval stage undergoes a varying number of instars (Gotthard, 2008). Individuals of a single species may also vary with the growth rates and instars. Under different photoperiods and between different phenotypic classes the growth rates of similar individuals vary considerably (e.g. males vs. females) (Nylin, 1992; Abrams et al., 1996). The life cycle studies of Acraea species from the Neotropics have been described with varying numbers of instars (same species) depending on the time of the year (photoperiod), seasonality, and mainly temperature (Henning and Williams, 2010). A. terpsicore was also reported to have six larval instars in Singapore (Khew, 2008). Given the background of this species nativeland presence and current range size-shifting, there was a need to investigate this invasive species in the context of the Borneo landscape where the species has gained a foothold. Therefore, the objectives of this study is to investigate comparative biology and morphology of the immature stages of $A$. terpsicore relative to habitat types; to assess the developmental outcomes in phenotype and gender. In addition to an immigrant Lepidopteran fauna of Borneo, $A$. terpsicore could serve as a threat to become a potential invasive species. Therefore, for future reference, its population indices were recorded for a duration of one year in this study.

\section{Materials and Methods}

The present study was carried out between April 2015 to 2016, in Sarawak Borneo, at the netted butterfly house and laboratory of Universiti of Malaysia Sarawak (UNIMAS) campus ( $1^{\circ} 27^{\prime} 53.8927^{\prime \prime} \mathrm{N}$, $\left.110^{\circ} 25^{\prime} 36.644^{\prime \prime} \mathrm{E}\right)$. Three study sites were selected for the comparative study of immature stages and behavior (Figure 1). Observations on the behavior of the immature stages were conducted in the laboratory while, for mating and oviposition the adults were kept in the netted house (Figure 2a, b). These sites were selected depending on the presence and extent of $A$. terpsicore occurrence inhabiting its primary host plant. a. Desa Ilmu (1²7’10.498” N, 110²7’26.83” E); Rural site (RS).

b. BDC (1³0’34.164” N, 110²1'34.149” E); Suburban site (SUS).

c. Jalan Stampin Barat (1³0'54.037” N, $\left.110^{\circ} 20^{\prime} 46.286^{\prime \prime} \mathrm{E}\right)$; Urban site (US).

Eggs of $A$. terpsicore were collected from the primary host plant $P$. foetida at three sampling sites and brought back to the laboratory, where they were maintained in plastic containers $(17 \mathrm{~cm} \mathrm{x} 12 \mathrm{~cm} \mathrm{x} 6 \mathrm{~cm})$ with $P$. foetida as a host plant. The life cycle study was carried out under controlled conditions $\left(\mathrm{T}^{\circ}=28^{\circ} \mathrm{C}\right.$ and photoperiod of 12:12 hrs of light and dark). For the adult feeding and oviposition, sufficient supply of nectar flowered plants (i-e, Lantana camara, Ixora coccinea and common Hibiscus rosa sinensis) and larval host plant ( $P$. foetida) were provided. 


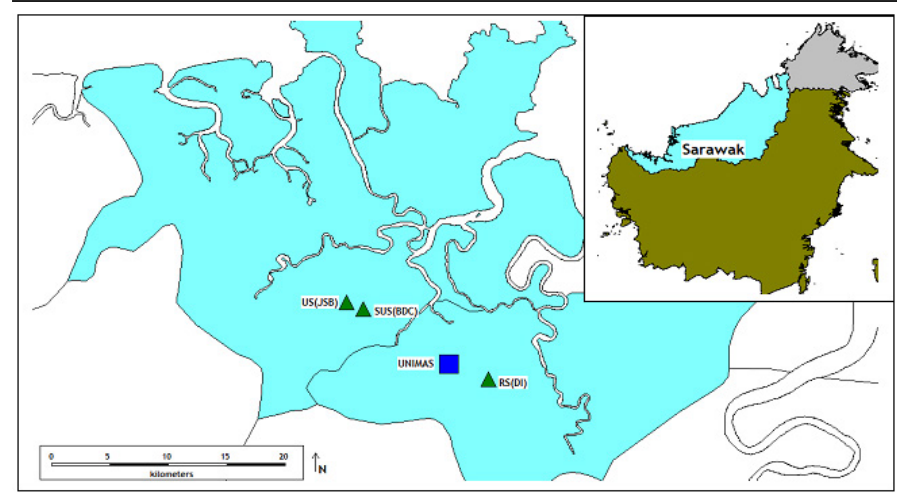

Figure 1: Map showing three sampling sites based on urbanization levels and UNIMAS campus. Inbox map holds the details of Sarawak and Borneo (Source: DivaGIS; 7.5).
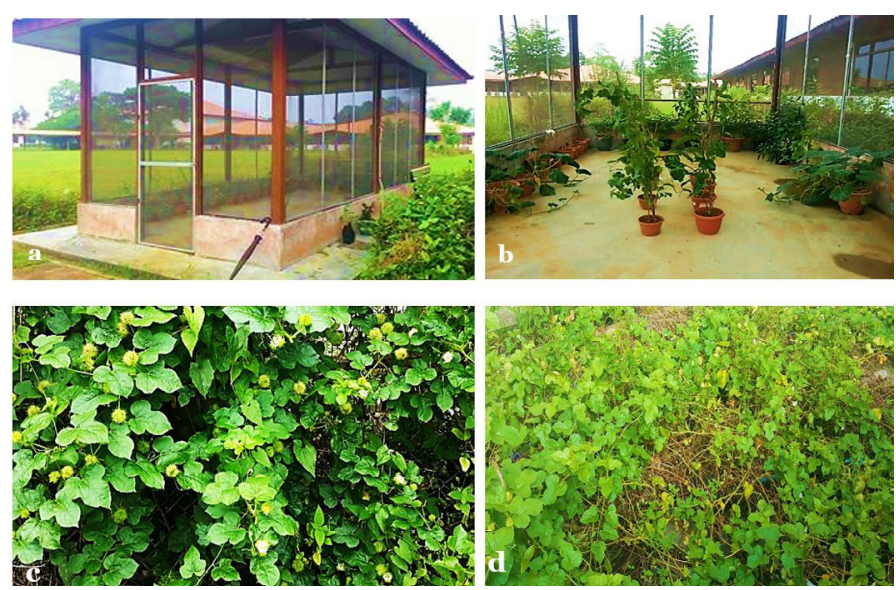

Figure 2: Study sites and host plant: (a) and (b) the netted house (butterfly) used for the events of mating and oviposition in the study (outside and inside view, respectively); (c) Primary food plant (Passiflora foetida) of $A$. terpsicore showing the lavish growth in the study site (DI); (d) Urban site (JSB) and the plentiful growth of host plant.

\section{Data collection}

The observations of the developmental time (Eggs to adult) were performed in the laboratory, while the adults were released in the netted house for mating and oviposition. From the firstly collected egg clusters, the F1 generation was utilized in the comparative study of immature stages. Among all the clusters obtained, six eggs were randomly separated from each cluster and observed for the developmental timeline (egg-adult). The percent (\%) survival of all the clusters at each stage was also recorded. Body length for each instar was measured using a millimeter scale and duration for each stage was recorded in days. For each larval instar, molting was ensured by examining the exuviae. The adults released in the netted house were keenly observed for mating behavior and oviposition, if failed for both the described events were then removed from the experiment (when found dead). Desa Ilmu (DI) was selected as the permanent site for monitoring $A$. terpsicore's population indices (following, Ruchi et al.,
2012). This site was selected based on the abundance of its primary host plant $P$. foetida. The site (DI) was visited twice weekly from April 2015-2016, and the presence and abundance of immature stages and adults were recorded separately with respect to mean temperature, relative humidity, and maximum rainfall throughout the observed duration.

\section{Data analysis}

The developmental data of $A$. terpsicore were analyzed and compared using basic statistics from three sites to evaluate the variance for body length $(\mathrm{mm})$ and duration (days) at each stage of the life cycle. The significance of the relationship between gender development in length and duration was analyzed by One-way ANOVA (MS Excel 2013).

\section{Results and Discussion}

\section{Courtship activities and mating behavior}

Copulation was often aerial where males usually grasped the female adult with the tarsal claws of thoracic legs and the pairing occurred end to end abdominally and normally lasted up to 2-3 hours (Figure 3c). The mating pair generally hangs upside down holding themselves with the help of a supporting leaf or branch of a plant. The females after mating were observed feeding on nectar and resting for approximately $24 \mathrm{hrs}$. Later the event of oviposition was observed, often at late morning hours until noon (i-e 1000 am -1200 pm). On several occasions, the newly emerged males were observed eagerly grasping other males for mating before they were released to the netted house (Figure 3a,b). This might be since males have only one chance of copulation in their lifetime and were intensely impatient to mate.

\section{Host plants and oviposition responses (Figure 3a-f)}

In all study sites $P$. foetida was frequently abundant and healthier (Figure 2c, 2). After 24 hrs of copulation or at least 18 hours later, the female was observed to be fluttering from plant to plant seeking a suitable leaf for oviposition. The surface areas of the leaf for oviposition were selected (observed) with very little or no trichomes (plant hairs) at all. Females alighted on the underside of the host plant for oviposition around noon and this event lasted for 2-3 hours (Figure 3f). In the field, eggs were found laid on those host plants that either already had larvae or egg batches (but not on the same leaf). However, on few occasions, the eggs were observed in 2-3 clutches on the same leaf 
and twice the eggs were found on the upper side of the leaf as well (Figure 3d, e). This might have been due to some sort of interruption that had occurred during the oviposition event or the surface area of the leaf might have ended further (as this butterfly generally choose the marginal area of $P$. foetida).
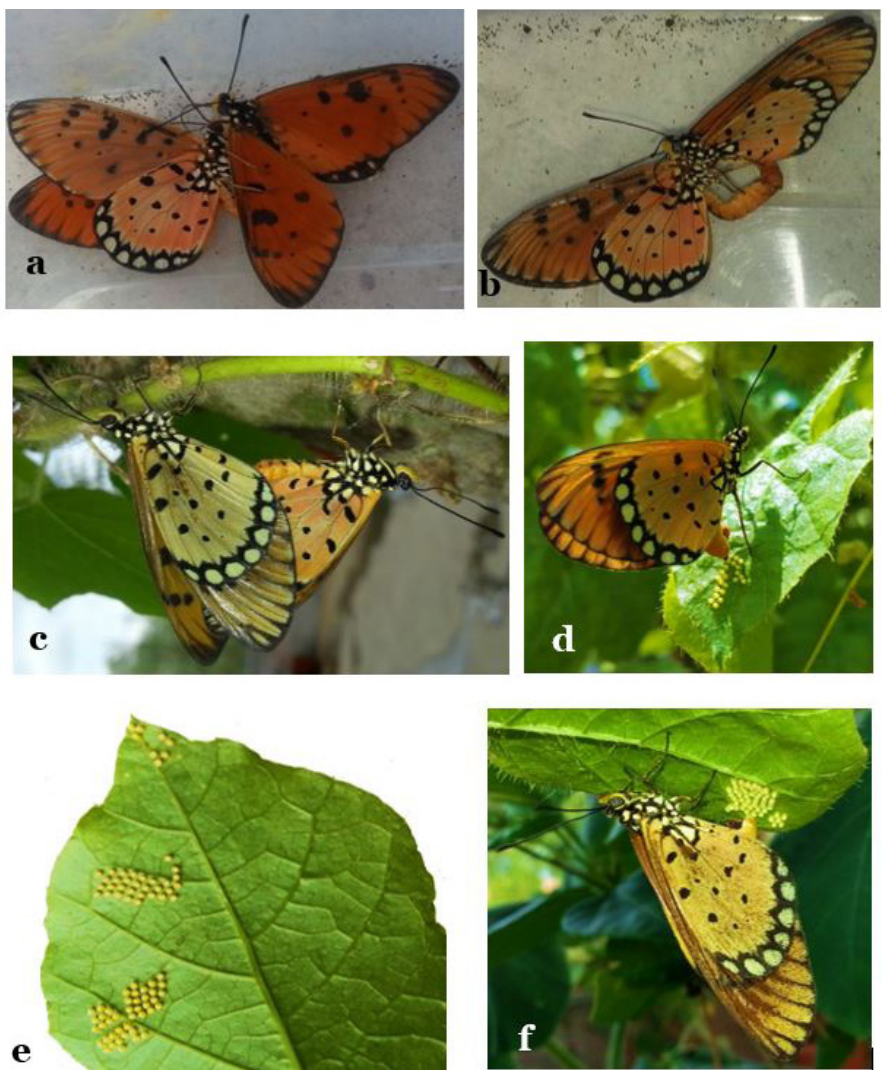

Figure 3: Courtship behaviour and oviposition in A. terpsicore: (a) and (b) Male adults grasping each other before released to the netted house, eager for mating (after emergence from pupa); (c) Mating pair in netted house; (d) Female ovipositing on the upper side of leaf ( $P$. foetida); (e) Patches of eggs laid at a single time on the same leaf of $P$. foetida; (f) Oviposition event.

External morphology of the immature stages eggs (Figure $4 \mathrm{a}-\mathrm{h})$

The eggs of $A$. terpsicore were generally laid in clusters and the number of eggs varied from $30-80$ per cohort. The typical egg measured about $0.5-0.7 \mathrm{~mm}$ in diameter and $0.8-0.9 \mathrm{~mm}$ in height $(\mathrm{n}=10)$. Eggs were barrel/olive shaped with pale yellowish in color. They were mostly laid in clusters on the underside of host plant leaves. The eggs adhered to the underside of leaves in an upright position and the glue surrounded the base of each egg is molded in a circular shield (Figure 4a). The barrel-shaped egg has 20 longitudinal ridges finely sculptured, runs from the base to apex and each ridge is separated with transverse grooves (Figure 4d). Micropyle at the apex of the egg usually forms a rosette with tiny ridges surrounded by a ring of polygonal cells. In Figure $4 \mathrm{~g}$, at the time of oviposition, eggs are pale yellowish in color and take about 48-60 hrs to change into black color. The egg stage in the life cycle of $A$. terpsicore lasted 2-3 days.
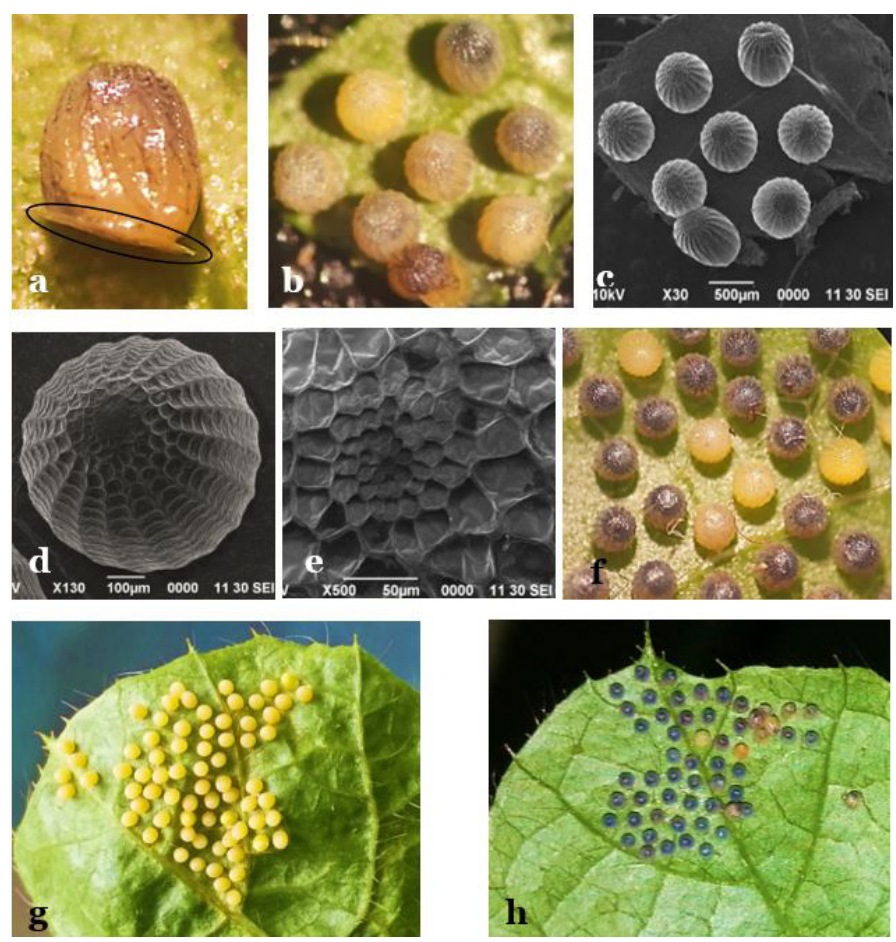

Figure 4: Eggs of A. terpsicore: (a) Lateral view of an egg with encircled area of glue (visible); (b) Top view of eggs under a Stereomicroscope; (c) Top view of eggs under SEM with a resolution of $\times 30$; (d) Single egg under SEM with a resolution of $x 130$; (e) Micropyle of an egg under SEM with a resolution of $x 500$; $(f)$ cluster of eggs with discrepancy; mature (black head) and under development (pale yellow); (g) Typical egg cohort (after oviposition); (b) cohort of mature eggs (8 hrs before hatching).

The eggs became translucent about 8-12 hrs prior to hatching. The change in color of the eggs is due to the development of immatures and formation of the head that gives the egg its black appearance (Figure 4a, b, h). Generally, in some cohorts few of the eggs that did not turn black and failed to hatch (Figure 4f). The eggs usually have a transparent protective liquid that covers the eggs throughout the embryonic period preventing them from dryness. Any fungal/bacterial attack on the egg or drying out might result in the failure of suitable development /hatching.

\section{First-instar larvae (Figure 5a-d)}

As the eggs hatched, the newly developed larva emerged through the micropyle and devoured the eggshell from inside. The first-instar larvae had a smooth round black head and paleyellowish cylindrical body covered with greyish black setae. Each seta arises from the sclerotized pinacula that protruded from the skin. Immediately after emergence, the first meal of larvae was its discarded eggshell. Once the 
food passes through the translucent skin, its color changed into creamy yellow. The prothoracic and anal shields turned dark brown within 6-12 hrs, while the rest of the abdominal body remained creamy yellow. The first-instar fed on the P. foetida leaves by eating the cuticle and making a hole near the surface where they emerged. Newly emerged larvae measured about 1-2 $\mathrm{mm}(\mathrm{n}=6)$ in length and grow up to $3.5 \mathrm{~mm}$. Approximately $24 \mathrm{hrs}$ later the $1^{\text {st }}$ instar turned into orange color and the stage lasted 3-4 days.
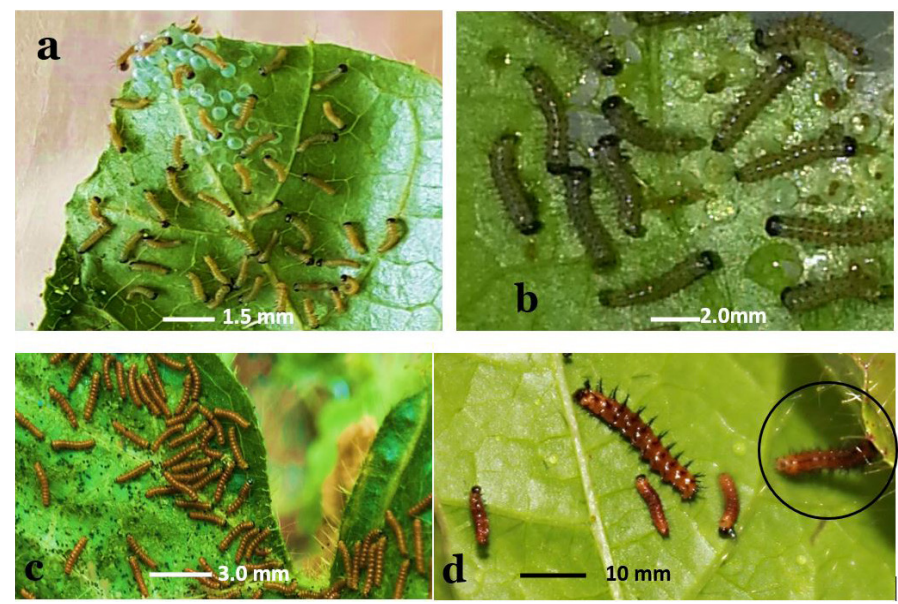

Figure 5: Immature stages of A. terpsicore: (a) Newly emerged $1^{\text {st }}$ instars and egg shells; (b) $1^{\text {st }}$ instar larvae after 12hrs; (c) gregarious group of $1^{\text {st }}$ instar larvae feeding on Passiflora foetida; (d) earlier $1^{\text {st }}$ instar and newly moulted (encircled) 2nd instar larvae on the same spot.

\section{Second-instar larvae (Figure 6a, b)}

The second-instar larvae exhibited a burnt orange body colour and a brown to black smooth head. The thoracic and anal segments were blackish in color. The thin and long setae of $1^{\text {st }}$ instar larva was transformed into dorsolateral black spines arranged in a row of six (numbers) on each body segment. The second-instar larvae possess the same cylindrical body and measure about $9-11 \mathrm{~mm}(\mathrm{n}=6)$ in length and the stage lasted 3-4 days. The individuals of second-instar remained together in-crowd and fed gregariously (Figure 6a). The second-instar larvae secreted a silken web around the leaf area as they fed along to prevent them from falling.

\section{Third-instar larvae (Figure 6c, d)}

The third-instar larva possessed the same features as the second instars and grew in size of up to $11-16 \mathrm{~mm}$ $(n=6)$ but slightly variable in coloration. The head, thorax, and last abdominal segments were paler than the rest of the body color which was dark chestnut. The spines grew with multiple lateral sub-branches. On the ventral side of larvae, the color remained pale yellowish.
This stage lasted up to 4-4.5 days, and the larvae were observed feeding irrepressibly throughout the period eradicating the traces of leaves. Upon disturbance, the larva usually exuded dark yellowish liquid from the posterior part of the body. The modification in the coloration of the newly molted third-instar and mature stage can be seen (Figure 6c, d).
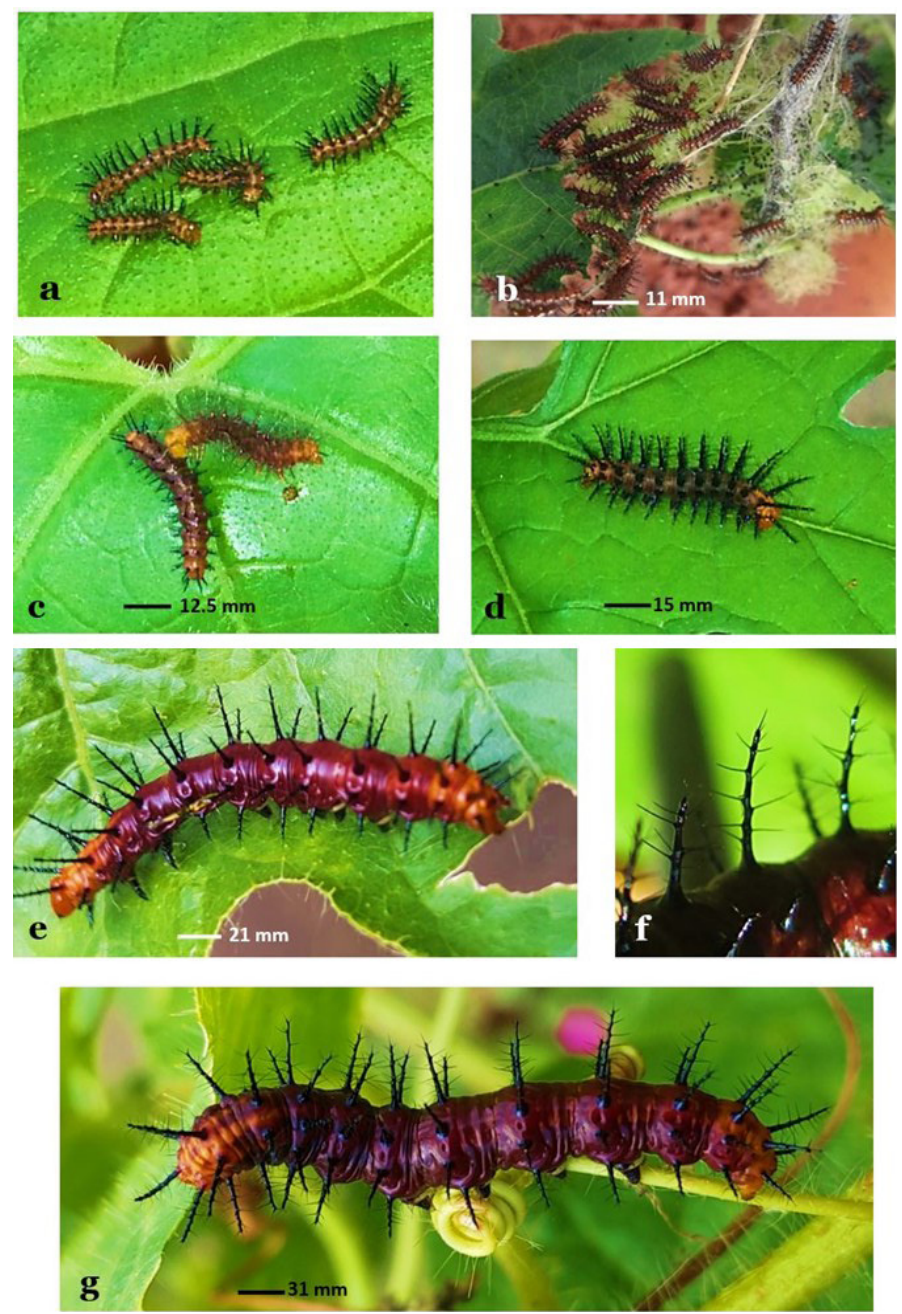

Figure 6: Immature stages of $A$. terpsicore: (a) fully grown second instar stage; (b) batch of $2^{\text {nd }}$ instars feeding gregariously, while the silken web can be visualized as well; (c) Newly moulted $3^{\text {rd }}$ instar; (d) fully grown third instar larva, (e) full sized fourth instar stage; (f) close up of the branched spines present in rows over each body segment on fourth instar larva; $(g)$ A fully grown fifth instar larva (last instar) of $A$. terpsicore.

\section{Fourth-instar larvae (Figure 6e, f)}

The fourth-instar larvae displayed no major differences apart from the lightening of body color from chestnut brown to purplish-brown. The head of the larva remained globular and the three thoracic and two last abdominal segments retained tawny orange color. On the ventral side, the pale yellow color transformed into greenish-yellow. The fully grown fourth-instar extended up to $21 \mathrm{~mm}(\mathrm{n}=6)$ in length and lasted in this stage about 3-4 days. After molting from the 
third into a fourth-instar stage, the larvae inflate their spines and were completely developed. Each of the spines has 8-12 sub lateral branches of black color (Figure 6f). The larvae of $A$. terpsicore were known to feed in groups on the host plant until second-instar but becomes completely solitary in its fourth-instar. The larvae fed and grew gradually in size day by day.

\section{Fifth-instar larvae (Figure 6g)}

The fifth-instar larvae of $A$. terpsicore was very similar to that of fourth-instar in appearance with a body length of about 28-31 mm $(\mathrm{n}=6)$ for a fully matured individual. The body color retained purplish-brown on the dorsal surface, whereas the ventral surface had the greenish-yellow color. The head was bright orange, whereas the thoracic and the last two abdominal segments displayed a deep orange color. There were several short black setae on the head and two long branched spines on the mesothorax. While on the Prothorax and Metathorax the spine/scoli were long and branched into four. This stage lasted for 4-5 days and the body grew massively while feeding on leaves, stems, and flower buds of the host plant.

\section{Pre-pupal stage (Figure 7a)}

The pre-pupal stage of $A$. terpsicore, started after the fifth instar larva spent about 4-5 days in that stage. The larva then ceased feeding and wandered around in search of fine places such as twigs of the host plant, on the underside of leaves, and sometimes away from the host plant in the grass/bushes. The pre-pupal stage lasted for 1-1.5 days and on several occasions, the larvae were observed molting while the pupation starts. During the pre-pupal stage, the larvae shrank about 2-3 $\mathrm{mm}(\mathrm{n}=6)$ in length and remained stationary if it found a suitable substratum (Figure 7a). In laboratory, the quiescent larvae usually chose side walls of plastic containers in which they were kept. White patches appeared on the lateral sides of thoracic segments during the last hours of the prepupal stage.

\section{Pupa (Figure 7b-d)}

The pupation took place during the quiescent stage as the last instar suspended vertically with the help of a short cremaster silk pad attached to the substrate. It took about 2-4 hrs for the pupae to reach full sclerotization and coloration. The pupae were white in color with one lateral (on both sides) and two dorsally arranged black bands. Each attained seven tawny orange spots at an equal distance. The ventral side of the pupa also had two black bands whereas, the costal and dorsum margins of the wing case possessed black stripes as well. The pupal stage lasted for 5-6 days. Approximately about $24 \mathrm{hrs}$ prior to eclosion, the pupa turned darker in the wing case and thorax region. Male individuals usually pupated a day earlier than the female individuals, while no major discrimination in the measurement of both sexes was observed. The length of the pupae measured about $20-23 \mathrm{~mm}(\mathrm{n}=6)$. The eclosion of the pupa took place during the 0600-1000 hrs and 1800-1100 hrs of the day. The emergence of adult/ imago occurred from the preapical area of the pupa and the adult rested on the pupal case for about 3-4 hours to allow the wings to dry completely (Figure 8a).
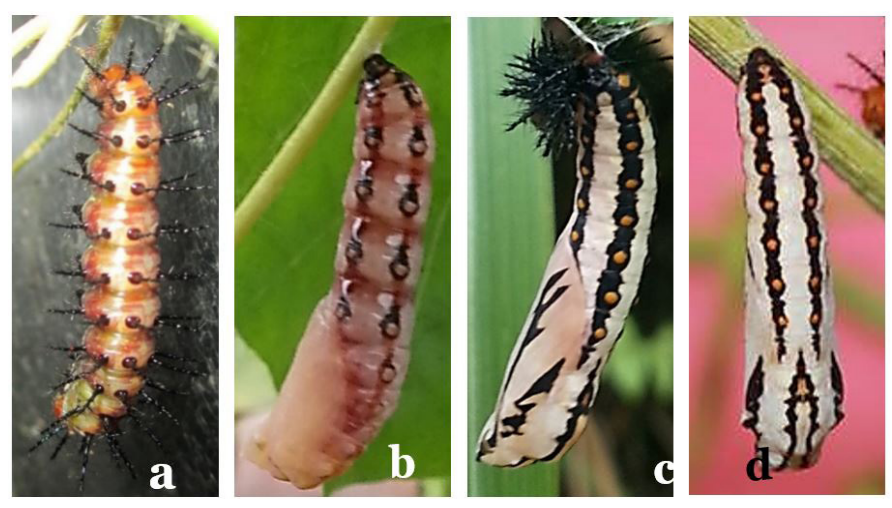

Figure 7: (a) Pre-pupal stage with visible white patches over the body; (b) Pupation stage and formation of wing case; (c) completely sclerotized pupa with last instar exuvia attached at the base (lateral view); (d) dorsal view of the fully matured pupa.

\section{Adults (Figure 8b-f)}

The head of adult $A$. terpsicore, which was hypognathous type and was entirely black with yellow scales arranged centrally on the fronto-clipial part. The globular compound eyes were reddish-brown along with ocular margins of bright yellow and hairy labial palps were present (Figure $8 \mathrm{~b}$ ). The antennae were clubbed, black, and possessed the flagellum that had the width of half of the scape, making it the distinguishing feature present amongst Acraeini.

The female had tapered black thorax but possessed a long and thick, dorsally amber-brown abdomen. The female wingspan measured about $50-65 \mathrm{~mm}$ and possessed an ochreous orange color, while the broad forewings were round at the apex (in both sexes) (Figure 8c, d). In contrast to the female, the male had a small thorax but the abdomen was long and narrow. Males were brighter in color as compare to females, which were dull in coloration. The wingspan of males was recorded to be about $40-50 \mathrm{~mm}$ and appeared 
reddish-orange to dark orange color (Figure 8e, f). Regardless of coloration and size both the male and female adults had the same wing pattern and could be distinctly identified in their usual habitat. In the field, A. terpsicore was more apparent owing to its bright tawny red coloration and lazy flight with distinctive wings shape. Both pairs of the wing were bordered black at the margins and turned out to be thicker by about $3 \mathrm{~mm}$ at the apex of the forewings. On hind wings, the black margins were much extensive and possessed a distinctive series of seven white spots in it. Adults were observed flying low and alighting on the ground frequently in the morning and afternoon hours of sunny days. While feeding on the nectar the adults can be caught easily by hand.

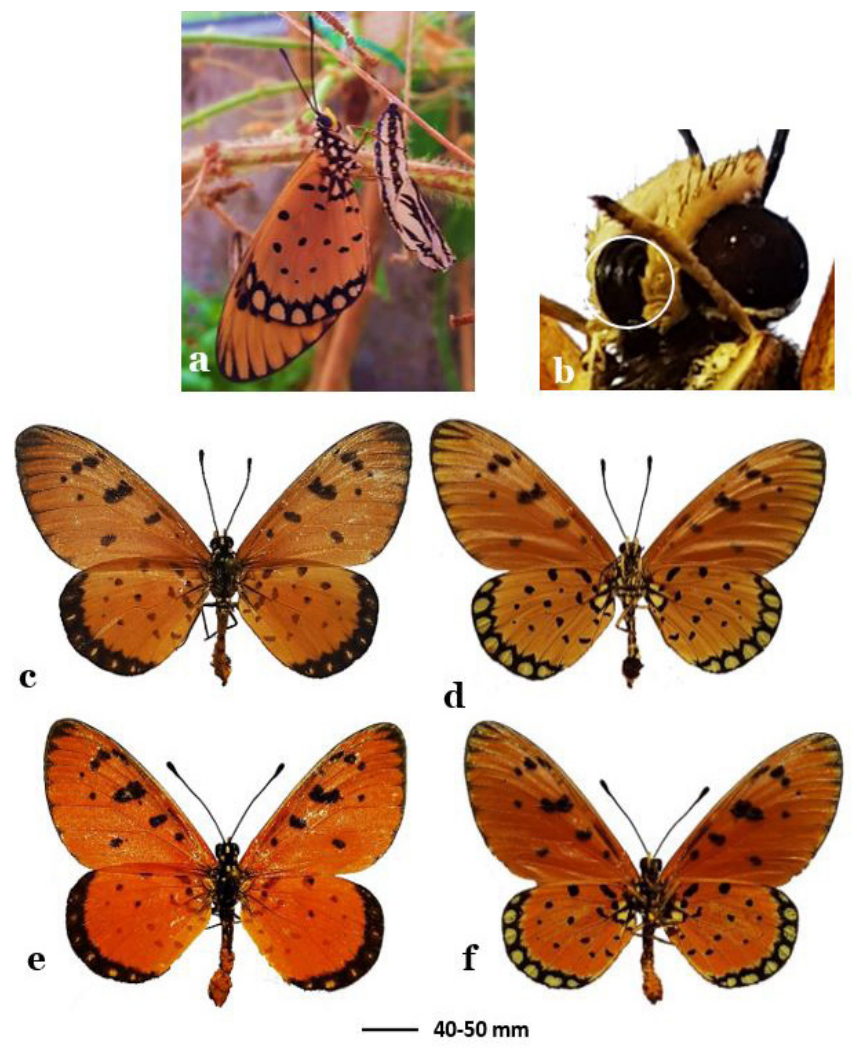

Figure 8: The adults of $A$. terpsicore: (a) Male adult emerged from pupa resting on the discarded pupal case; (b) head of the imago with visible compound eyes, labial palps (hairy, yellow) and coiled proboscis (encircled); (c) Female upper side; (d) female under side; (e) Male upper side; $(f)$ Male under side.

Comparison of developmental cycle relative to habitat types

The period of development from egg to adult was approximately 30-32 days that passed through five larval instars. The body length of first to fifth larval instars analyzed for the three habitat types was averaged to $3.231 \pm 025,9.578 \pm 0636,14.802 \pm$ $0.721,20.533 \pm 0.721$ and $29.92 \pm 0.915$, respectively. Table 1 shows the rural site (RS), individuals duration in larval instars was averaged to $3 \pm 0,3.083 \pm 0.189$, $4.086 \pm 0.191,4.176 \pm 0.323$ and $4.288 \pm 0.396$. The development time averaged for the suburban site (SUS) immatures in the five larval instars were $3 \pm$ $0,3.083 \pm 0.192,3.972 \pm 0.469,3.821 \pm 0.249$ and $4.346 \pm 0.427$, respectively. Cohorts from the urban site (US) studied for the developmental cycle took an average of $3 \pm 0,3.167 \pm 0.241,3.854 \pm 0.403,3.979$ \pm 0.179 and $4.182 \pm 0.363$ days, among first to fifth larval instars. No significant difference was observed in the body length and duration taken by each stage (days) of $A$. terpsicore in life cycle studies relative to habitat types.

\section{Survival rate recorded among all the cohorts}

The overall data of this study was compiled for the percent (\%) survivorship of each stage conquering the developmental phases to become an adult, among all the cohorts of $A$. terpsicore. The total survival rate recorded was $71.8 \%$ for successful adults (Figure 9). The gender ratio among the survived adults was almost equal. For stages egg-third instar the ratio of survival was approximately 90\%. However, the percentage dropped in the fourth and fifth larval instars. Consequently, about $5 \%$ of the individuals failed to pupate and the emergence ratio to the adult stage was $71.8 \%$, hence, less than $2 \%$ of pupae being compromised to emerge successfully.

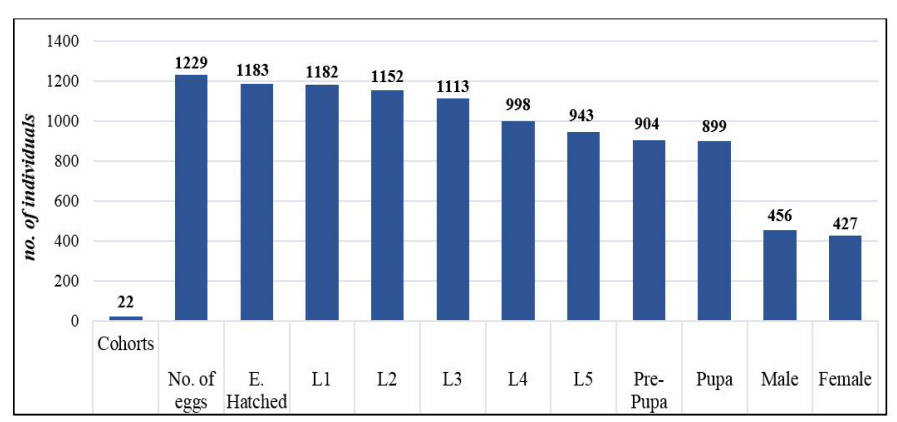

Figure 9: The overall survivorship rate of each developmental stage of $A$. terpsicore for 22 cohorts.

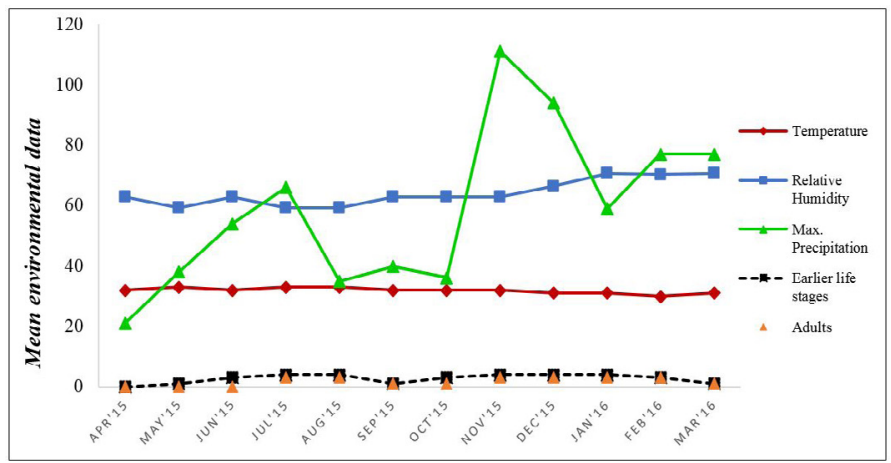

Figure 10: Population index of $A$. terpsicore, in relation to the average temperature, relative humidity and maximum precipitation throughout the duration. 
Table 1: Comparative summary of A. terpsicore developmental timeline (Body length and duration) from three study sites.

\section{Duration (days)}

\begin{tabular}{|c|c|c|c|c|c|c|c|c|c|c|c|c|}
\hline & & Min & $\operatorname{Max}$ & Mean & $\pm \mathrm{SD}$ & SE & Min & Max & Mean & $\pm \mathrm{SD}$ & SE & $\begin{array}{l}\text { Range } \\
\text { (days) }\end{array}$ \\
\hline & Eggs & & & & & & 2.5 & 3 & 2.75 & 0.25 & 0.042 & $1-3$ \\
\hline Rural & L1 & 3 & 3.5 & 3.278 & 0.252 & 0.042 & 3 & 3 & 3 & 0 & 0 & $3-7$ \\
\hline site & $\mathrm{L} 2$ & 9 & 11 & 9.708 & 0.59 & 0.098 & 3 & 3.5 & 3.083 & 0.189 & 0.031 & $7-11$ \\
\hline \multirow[t]{8}{*}{ (RS) } & L3 & 14 & 16 & 15.157 & 0.65 & 0.11 & 4 & 4.5 & 4.086 & 0.191 & 0.032 & $11-14$ \\
\hline & L4 & 19 & 22 & 20.456 & 0.838 & 0.144 & 4 & 5 & 4.176 & 0.323 & 0.055 & $14-18$ \\
\hline & L5 & 28 & 31 & 29.97 & 0.918 & 0.16 & 4 & 5 & 4.288 & 0.396 & 0.069 & $18-23$ \\
\hline & Pre-Pupa & 23 & 28 & 26.288 & 1.571 & 0.274 & 0.5 & 1.5 & 0.879 & 0.251 & 0.044 & $23-24$ \\
\hline & Pupa & 19 & 23 & 21.561 & 1.044 & 0.182 & 4.5 & 6.5 & 5.379 & 0.573 & 0.1 & $24-30$ \\
\hline & Adult (B.L) & 14 & 16.5 & 15.288 & 0.673 & 0.117 & & & & & & \\
\hline & Wingspan & 38 & 49 & 43.182 & 2.893 & 0.504 & & & & & & \\
\hline & Eggs & & & & & & 2.5 & 3 & 2.833 & 0.243 & 0.057 & $1-3$ \\
\hline \multirow{10}{*}{$\begin{array}{l}\text { Suburban site } \\
\text { (SUS) }\end{array}$} & $\mathrm{L} 1$ & 3 & 3.5 & 3.25 & 0.257 & 0.061 & 3 & 3 & 3 & 0 & 0 & $3-7$ \\
\hline & L2 & 9 & 11 & 9.528 & 0.581 & 0.137 & 3 & 3.5 & 3.083 & 0.192 & 0.045 & $7-11$ \\
\hline & L3 & 14 & 16 & 14.972 & 0.776 & 0.183 & 3 & 4.5 & 3.972 & 0.469 & 0.11 & $11-14$ \\
\hline & L4 & 19 & 22 & 20.643 & 0.864 & 0.231 & 3.5 & 4 & 3.821 & 0.249 & 0.066 & $14-18$ \\
\hline & L5 & 28 & 31 & 29.615 & 0.961 & 0.266 & 4 & 5 & 4.346 & 0.427 & 0.119 & $18-23$ \\
\hline & Pre-Pupa & 24 & 28 & 25.885 & 1.46 & 0.405 & 0.5 & 15 & 1 & 0.289 & 0.08 & $23-24$ \\
\hline & Pupa & 20 & 23 & 21.5 & 1.08 & 0.3 & 5 & 6 & 5.615 & 0.506 & 0.14 & $24-30$ \\
\hline & Adult(B.L) & 14 & 16.5 & 15.154 & 0.851 & 0.236 & & & & & & \\
\hline & Wingspan & 38 & 49 & 43.308 & 3.881 & 1.076 & & & & & & \\
\hline & Eggs & & & & & & 2.5 & 3 & 2.667 & 0.241 & 0.049 & $1-3$ \\
\hline Urban & $\mathrm{L} 1$ & 3 & 3.5 & 3.167 & 0.241 & 0.049 & 3 & 3 & 3 & 0 & 0 & $3-7$ \\
\hline site & $\mathrm{L} 2$ & 8 & 11 & 9.5 & 0.737 & 0.15 & 3 & 3.5 & 3.167 & 0.241 & 0.049 & $7-11$ \\
\hline \multirow[t]{7}{*}{ (UB) } & L3 & 13 & 16 & 14.279 & 0.737 & 0.15 & 3 & 4.5 & 3.854 & 0.403 & 0.082 & $11-14$ \\
\hline & L4 & 19 & 22 & 20.5 & 0.978 & 0.2 & 3.5 & 4.5 & 3.979 & 0.179 & 0.037 & $14-18$ \\
\hline & L5 & 28 & 31 & 30.182 & 0.867 & 0.185 & 4 & 5 & 4.182 & 0.363 & 0.077 & $18-23$ \\
\hline & Pre-Pupa & 24 & 28 & 26.25 & 1.193 & 0.254 & 0.5 & 1.5 & 1.023 & 0.188 & 0.04 & $23-24$ \\
\hline & Pupa & 20 & 23 & 21.432 & 0.623 & 0.133 & 4 & 6.5 & 5.432 & 0.563 & 0.12 & $24-30$ \\
\hline & Adult(B.L) & 14 & 16.5 & 15.432 & 0.695 & 0.148 & & & & & & \\
\hline & Wingspan & 38.5 & 54 & 45.614 & 4.879 & 1.04 & & & & & & \\
\hline
\end{tabular}

Table 2: Population indices of $A$. terpsicore, relative to mean temperature, relative humidity and maximum precipitation at specific monthly time.

$\begin{array}{lllllllllllll}\text { 2015-2016 } & \text { Apr } & \text { May } & \text { Jun } & \text { Jul } & \text { Aug } & \text { Sep } & \text { Oct } & \text { Nov } & \text { Dec } & \text { Jan } & \text { Feb } & \text { Mar } \\ \text { Larval stage } & * * * * & * * * & * & * * & * * * & * * * & * * * & * * * & * * & * & * * & * * \\ \text { Adults } & * * * & * * * & * * & * * & * * * & * * * & * * * & * * * & * * & - & * & * * \\ \text { Mean temperature }\left({ }^{\circ} \mathrm{C}\right) & 32 & 33 & 32 & 33 & 33 & 32 & 32 & 32 & 31 & 31 & 30 & 31 \\ \text { (Av.) R. humidity \% } & 62.8 & 59.3 & 62.7 & 59.3 & 59.3 & 62.7 & 62.7 & 62.7 & 66.4 & 70.5 & 70.3 & 70.5 \\ \text { Precipitation } & 21.1 & 38.1 & 54.1 & 66 & 35 & 39.9 & 36.1 & 111 & 94 & 58.9 & 77 & 77\end{array}$

-: not found; ": Rare; **: Common; ${ }^{* * * *}$ : Very common; Weather data retrieved from www.weatherunderground.com. 
Population index

The rural site (DI) was visited for its population indices and the data record is summarized in Table 2. The detection of $A$. terpsicore in the study site was evaluated for the observation of both the immature stages and adults if sighted. Whereas, if undetected does not necessarily relate to the absence of a species, but might not be detected while present. Overall the presence of immature stages compared to the adults was recorded more frequently, as the immatures tend to remain gregarious and were not too mobile. While the adult's mobility (flight) makes them harder to be detected at a specific location. Therefore, the observational data were arranged $\left({ }^{*}=\right.$ rare, ${ }^{* *}=$ common and ${ }^{* * *}$ more common) with respect to the sighting, once in four weeks, twice and thrice times in four weeks of a month. Figure 10 represents the population indices with relation to the monthly mean temperature, relative humidity, and maximum precipitation.

Acraea terpsicore was recorded to be one of the prominent species from the tribe Acraeini and is distributed widely through the Indian and Sri Lankan region. With the passage of time, the effect of climate change and habitat modification forced this species to invade geographical regions that lie far more beyond than its native range (Arshad et al., 1996; Khew, 2008; Braby et al., 2013, 2014). It took about three decades for $A$. terpsicore to invade the Southeast region leading to Australia through the path of the Greater Sunda Islands (Matsumoto et al., 2012; Braby et al., 2013; Florida et al., 2015; Iqbal et al., 2015). Since its first sighting in Sarawak, Abang et al. (2016) detected as a non-indigenous as well as an addition into the list of invasive species.

The host plant in Borneo was initially P. foetida, which is also referred to as the common ancestral plant for the tribe Acraeini (Pierre and Bernaud, 1997; Iqbal et al., 2015). The oviposition response encountered at all the sites varied between 30-85 eggs in number and were laid on the underside marginal areas of soft leaves (Braby et al., 2014). Comparative analysis of life cycle studies revealed that the time duration taken by $A$. terpsicore from the three study sites was approximately $30 \pm 3.01$ days. However, in 2014, for general observation, the developmental duration was obtained about 30-40 days at the same rural site (DI). Since, in butterflies, the overall development time and instar duration are influenced mainly by temperature
(Braby, 2003). However, the record annual mean temperature in 2014 was recorded at $28^{\circ} \mathrm{C}$, which was similar to that of 2015. This could possibly be due to arriving into new geographic land, decision making was essential to adopt better choices for survival by prioritizing establishment and later to spread.

The total development time taken by each individual in a single cohort to complete one life cycle was directly related to the duration spent by each stage and the number of instars. Among the members of the Acraeini, most of the species were reported to exhibit five to seven larval instars in the same cohort (Henning and Williams, 2010). As for A terpsicore in Singapore (Khew, 2008), a total of six larval instars were reported. In this current study five larval instars with similar body length as documented by Khew (2008) was recorded. Eggs took almost three days to hatch, and the first meal of the newly hatched instars was the discarded chorion. Whereas, in Australia, few of the cohorts kept in captivity were reported to last seven days in their egg stage and the newly hatched larvae did not consume the eggshell (Braby et al., 2014). The earlier larval instars ( $1^{\text {st }}$ to $\left.3^{\text {rd }}\right)$ were gregarious and became more isolated in the last instars. This is a common behavior among other Acraeini species (Kunte, 2000; Henning and Williams, 2010; Velez et al., 2011). The average body length for the first to fifth larval instars was attained as $3.231 \pm 025,9.578 \pm 0636,14.802 \pm 0.721,20.533$ \pm 0.721 and $29.92 \pm 0.915$, respectively. No significant difference was recognized among the immatures of A. terpsicore in body length and duration compared for the three habitat types. Development of the larvae was accomplished without any interruption of diapause (Braby et al., 2014). Hypothetical tests resulted in a positive correlation between the pupal size and wingspan and also among pupal size and pupal duration, regardless of the sex differentiation in A. terpsicore (Wiklund and Karlsson, 1984). The males usually pupated a day earlier than the females and this finding is supported by Kunte and Gadgil (2001).

In female adults of $A$. terpsicore, the wingspan was about $50-60 \mathrm{~mm}$ between the apical margins of the front wings with ochreous orange color. Compared to the females, the male displayed a much brighter orange color and has a wingspan of about $40-50 \mathrm{~mm}$. Regardless of coloration and size, both male and female adults were observed to have similar wing patterns and can be distinctly identified in its usual 
habitat. This is in accordance with Eltringham (1912); Pierre and Bernaud (1997) and Braby et al. (2014). In the field $A$. terpsicore was more apparent owing to its bright tawny red coloration and lazy flight pattern with distinctive wing shape (Kunte and Gadgil, 2001; Hoskins, 2014). Adults were observed to be flying low at about 2-3 meters from the ground frequently in the morning and afternoon hours of sunny days (Braby et al., 2014).

Besides the common behavior and characters of A. terpsicore for the survivorship rate of each stage conquering the developmental phases successfully to become an adult was $71.8 \%$ overall. However, the ratio for both male and female adults during this study quite significantly remained in equal proportion $(52 \%$ males and $48 \%$ females, overall) which has been also reported from some other members of Heliconiinae (Clarke and Sheppard, 1975). Population indices for the abundance were evaluated as to be common during the yearly duration but drops during the months with higher precipitation.

\section{Conclusions and Recommendations}

In conclusion, no major discrimination was obtained in the comparative biology studies relative to that of three habitat types based on urbanization levels. In this novel range, this species also has a similar developmental duration (days) as described in other recent studies. This species was found to feed voraciously on its primary host plant $P$. foetida in this newly invaded range. In general, $A$. terpsicore has already been reported from several locations of Borneo and its future distribution to the nearby regions will likely to happen. This might create a chance of overlapping the geographical range and increases the chance of competing for the native biodiversity. Which could possibly lead to becoming either an invasive pest or to the extinction of the other species.

\section{Acknowledgements}

The authors are thankful to the authorities of Universiti of Malaysia Sarawak, for the utilization of netted butterfly house in the research project.

\section{Novelty Statement}

This manuscript covers an initial and comprehensive statement about the biology of a novel butterfly in context to its newly extended range i.e., Sarawak, Borneo.

\section{Author's Contribution}

Sabina Noor: Arranged and transcribed the manuscript.

Fatimah Bt. Abang: Reviewed and analyzed the data for the manuscript.

Hamady Dieng: Designed and formulated the methodology for this study.

\section{Conflict of interest}

The authors have declared no conflict of interest.

\section{References}

Abang, F., S. Noor, R. Hazali and H. Dieng. 2016. First record and occurrence of Acraea terpsicore (Linnaeus, 1758) (Lepidoptera: Nymphalidae) in Malaysian Borneo. Serangga, 21(2): 21-31.

Abrams, P.A., O. Leimar, S. Nylin and C. Wiklund. 1996. The effect of flexible growth rates on optimal sizes and development times in a seasonal environment. Am. Nat., 147(3): 381-395. https://doi.org/10.1086/285857

Arshad, S.J., C.Y. Chong, B.K. Jemadi and H.R.M. Story. 1996. Butterfly News (updated regularly!). Malayan Nat., 49: 9-12.

Braby, M.F., 2003. Effect of temperature on development and survival in Delias nigrina $\left(\mathrm{Fa}^{-}\right.$ bricius) (Lepidoptera: Pieridae). Aust. J. Entomol., 42: 138. https://doi.org/10.1046/j.14406055.2003.00342.x

Braby, M.F., B.M. Thistleton and M.J. Neal. 2014. Host plants, biology and distribution of $A c-$ raea terpsicore (Linnaeus, 1758) (Lepidoptera: Nymphalidae): A new butterfly for Northern Australia with potential invasive status. Austral. Entomol., 53: 288-297. https://doi. org/10.1111/aen.12078

Braby, M.F., C.S. Bertelsmeier, C. Sanderson and B.M. Thistleton. 2013. Spatial distribution and range expansion of tawny coster butterfly, $A c^{-}$ raea terpsicore (Linnaeus, 1758) (Lepidoptera: Nymphalidae), In: South-East Asia and Australia. R. Entomol. Soc. Insect Conserv. Divers., 7(2): 1-12. https://doi.org/10.1111/icad.12038

Clarke, C. and P.M. Sheppard. 1975. All female broods in the butterfly Hypolimnas bolina (L.). Proc. R. Soc. Lond. Br., 189: 29-37. https://doi. 
org/10.1098/rspb.1975.0038

Das, R.P., A.B. Roy, R. Polley and G. Saha. 2010. A new Record on the larval host plant of tawny coster Acraea violae (Fabricius). J. Bombay Natl. History Soc., 107: 63.

Eltringham, H., 1912. A monograph of African species of the genus Acraea. Fab. With a supplement on those of the oriental region. Trans. Entomol. Soc. Lond., 1: 374.

Emmel, T.C. and J.B. Heppner. 1990. Lepidoptera colleting in Taiwan. Trop. Lepidoptera, 1(2): 43-52.

Fabricius, J.C., 1798. Entomologia Systematica emendata et aucta, secundum classes, ordines, genera, species adjectis synonimis locis observationibus descriptionibus. Hafniae. I-IV. Suppl. Entomol. Syst. Copenhagen, pp. 1-572.

Florida, M., T.R. Setyaweti, and A.H. Yanti. 2015. Inventarisasi Jenis Kupu-Kupu pada hutan kerangas di kawasan Cagar Alam Mandor Kabupaten Landak. J. Protobiont., 4(1): 260-265.

Fox, R.M., A.W.H. Lindsey, K. Clench and L.D. Miller. 1965. Memories of the American entomological society; Butterflies of Liberia. Am. Entomol. Soc., 19: 189-200.

Freitas, A.V.L. and K.S. Brown Jr. 2004. Phylogeny of the nymphalidae (Lepidoptera). Syst. Biol., 53(3): 363-383. https://doi. org $/ 10.1080 / 10635150490445670$

Garcia-Barros, E., 2000. Body size, egg size, and their interspecific relationship with ecological and life history traits in butterflies (Lepidoptera: Papilionoidae, Hesperioidea). Biol. J. Linn. Soc., 70: 251-284. https://doi. org/10.1111/j.1095-8312.2000.tb00210.x

Gotthard, K., 2008. Adaptive growth decisions in butterflies. BioSci., 58(3): 222-230. https://doi. org/10.1641/B580308

Henning, G.A. and M.C. Williams. 2010. Taxonomic notes on the afrotropical taxa of the tribe acraeini (Boisduval, 1833) (Lepidoptera: Nymphalidae: Heliconiinae). Metamorphosis, 21(1): 1-38.

Henning, G.A., 1992. Phylogenetic notes on the African species of the subfamily AcraeinaePart 1 (Lepidoptera: Nymphalidae). Metamorphosis, 3(3): 100-114.

Hoskins, A., 2014. A learn about butterflies: the complete guide to the world of butterflies and moths. Reed New Publishers Holland. (www. learnaboutbuterflies.com).
Hübner, J., 1819. (Acraea) in GBIF Secretariat (2019). GBIF Backbone Taxonomy. Checklist dataset https://doi.org/10.15468/39omei accessed via GBIF.org on 2020-12-15.

Iqbal, M., Haryadi and Syafuri.2015. Tawny Coster Acraea terpsicore. A new species for Borneo? J. Indones. Natl. History, 3(2): 47-49.

Kaur, M., H.S. Rose and A.K. Sidhu. 2009. The life history of tawny coster, Acraea terpsicore (Linnaeus) (Lepidoptera: Nymphalidae: Acraeinae). Ann. For., 17: 108-112.

Khew, S.K., 2008. Butterflies of Singapore. The Voyage of the Tawny Coster (Acraea violae). http:// butterflycircle.blogspot.com.au/2008/03/voyage-of-tawny-coster.html. (Accessed on $10^{\text {th }}$ July 2014).

Kunte, K. and M. Gadgil. 2001. India a lifescape: Butterflies of Peninsular India. Universities Press (India) Pvt. Ltd, 2000. pp. 118-120.

Kunte, K., 2000. Butterflies of Peninsular India. University press Hyderabad. pp. 254.

Larsen, T.B., 2005. Butterflies of the West Africa. Apollo Books, Stenstrup, Denmark. pp. 270.

Linnæus, C., 1758. Systema naturæ per regna tria naturæ, secundum classes, ordines, genera, species, cum characteribus, differentiis, synonymis, locis. Tomus I. Insecta, $10^{\text {th }}$ Edition decima, reformata. Online; www.biodiversitylibrary. org/page/726886\#page/3/mode/1up. https:// doi.org/10.5962/bhl.title.542

Matsumoto, K., W.A. Noerdjito and E. Cholik. 2012. Butterflies recently recorded from Lambok. Treubia, 39: 27-40.

Nylin, S., 1992. Seasonal plasticity in life history traits: Growth and development in Polygonia c-album (Lepidoptera: Nymphalidae). Biol. J. Linn. Soc., 47: 301-323. https://doi. org/10.1111/j.1095-8312.1992.tb00672.x

Pierre, J. and D. Bernaud. 1997. Acraea terpsicore (Linne'), Problems de nomenclature et donees biologiques (Lepidoptera, Nymphalidae). Bull. Soc. Entomol. France, 102: 405-412.

Ruchi, N., G. Nirjara, and P. Sujatha. 2012. What determines the abundance of butterflies? A short search. Recent Res. Sci. Technol., 4(11): 28-33. http://recent-science.com/.

Van Son, G., 1963. The butterflies of Southern Africa. Part 3. Nymphalidae: Acraeinae. Transvaal Museum Memories. 14: 130.

Vane-Wright, R.I. and R.D. Jong. 2003. The Butterflies of Sulawesi: annotated check-list for a 
critical Island fauna. Natl. Natur. Mus. Leiden, 343: 229-236.

Velez, P.D., H.H.V. Montoya and M. Wolff. 2011. Immature stages and natural history of the Andean butterfly Altinote ozomene (Nymphalidae: Heliconiinae: Acraeini). Zoologia, 28(5): 593-602. https://doi.org/10.1590/S198446702011000500007

Waterhouse, D.F. 1994. Biological control of Weeds: Southeast Asian Prospects. Aust. Cen- tre Int. Agric. Res., pp. 275.

Wiklund, C. and B. Karlsson. 1984. Egg size variation in satyrid butterfly's adaptive vs historical, "Bauplan" and mechanistic explanations. OIKOS Copenhagen, 43: 391-400. https://doi. org/10.2307/3544158

Wikramayanke, A. and A. Wikramayanke. 2006. Butterflies of Sri Lanka. Wikramayanke, Colombo, Sri Lanka. pp. 306. 